\title{
Relationship Between Budget Participation, Job Characteristics, Emotional Intelligence and Work Motivation As Mediator Variables to Strengthening User Power Performance: An Emperical Evidence From Indonesia Government
}

\author{
Heri Sandi', Nur Afni Yunita², Mohd.Heikal ${ }^{3}$, Rico Nur Ilham ${ }^{4}$, Irada Sinta ${ }^{5}$ \\ ${ }^{1}$ Faculty of Economic and Business Universitas Batam \\ herisandii@gmail.com \\ ${ }^{2,3,4}$ Faculty of Economic and Business Universitas Malikussaleh \\ nurafni.yunita@unimal.ac.id, mohd.heikal@unimal.ac.id, \\ ${ }^{5}$ Faculty of Agriculture Universitas Malikussaleh \\ nurafni.yunita@unimal.ac.id, mohd.heikal@unimal.ac.id,
}

Coresponding Author: riconurilham@unimal.ac.id

\begin{abstract}
In this study, researchers used respondent data, such as gender, age and length of employment of respondents in order to provide information about the characteristics of respondents. Where from the questionnaires distributed as many as 186 . The discussion in this chapter is the result of field studies to obtain data on answers to questionnaires that measure the five main variables in this study, namely budget participation, job characteristics, emotional intelligence, work motivation and power performance of budget users. Data analysis with parametric and non-parametric statistics using SEMPLS (Structural Equation Modeling-Partial Least Square) regarding research variables, instrument testing, normality testing, hypothesis testing, and discussion of the results of hypothesis testing and Path Analysis. The effect of the X3 variable on X4 has a P-Values value of $0.000<0.05$, so it can be stated that the effect of $\mathrm{X} 3$ on $\mathrm{X} 4$ is significant. The effect of the $\mathrm{X} 3$ variable on $\mathrm{Y}$ has a P-Values value of $0.000<0.05$, so it can be stated that the effect of X3 on $\mathrm{Y}$ is significant. The effect of the $\mathrm{X} 4$ variable on $\mathrm{Y}$ has a P-Values value of $0.213<0.05$, so it can be stated that the effect of $\mathrm{X} 4$ on $\mathrm{Y}$ is significant. The effect of the X1 variable on X4 has a P-Values value of $0.066>0.05$, so it can be stated that the effect of $\mathrm{X} 1$ on $\mathrm{X} 4$ is not significant. The effect of the $\mathrm{X} 1$ variable on $\mathrm{Y}$ has a P-Values of $0.481>0.05$, so it can be stated that the effect of $\mathrm{X} 1$ on $\mathrm{Y}$ is not significant. The effect of the $\mathrm{X} 2$ variable on $\mathrm{X} 4$ has a $\mathrm{P}$ Values value of $0.251>0.05$, so it can be stated that the effect of $\mathrm{X} 2$ on $\mathrm{X} 4$ is not significant. The effect of the X2 variable on $\mathrm{Y}$ has a P-Values value of $0.124>0.05$, so it can be stated that the effect of X2 on $\mathrm{Y}$ is not significant.
\end{abstract}

Keywords: Budget Participation, Job Characteristics, Emotional Intelligence, Work Motivation, Budget User Power Performance

\section{PRELIMINARY}

After a long-time joining Riau, the Riau Islands finally decided to separate themselves by forming the Struggle Agency for the Establishment of the Riau Islands Province (BP3KR). BP3KR's struggle finally paid off with the expansion of the Riau Islands province from Riau on September 24, 2002. The Riau Islands is the 32nd province in Indonesia based on Law No. 25 of 2002 covering Tanjung Pinang City, Batam City, Bintan Regency, Karimun 
Regency, Natuna Regency, Anambas Regency and Lingga Regency. Geographically, the Riau Islands province is bordered by neighboring countries, namely Singapore, Malaysia, and Vietnam which has an area of $251,810.71 \mathrm{~km}^{2}$ with 96 percent of which is waters with 1,350 large and small islands, which have shown progress in implementing government, development and community activities. The capital city of the Riau Islands province is located in Tanjungpinang. This province is located on a strategic sea and air transportation traffic lane, and is the busiest at the international level and on the lips of a world market that has market opportunities.

In empowering various existing potentials, the Riau Islands Province strives to continue to create a conducive investment climate through the implementation of good governance and clean government by providing easy investment so that it can attract more domestic and foreign investors to invest their capital. It is hoped that with the implementation of these two things (good governance and clean government) by all employees of the Riau Islands Provincial Government, it is also hoped that a dynamic work climate will be created so that all parties put full trust in the Riau Islands Provincial Government.

The Riau Islands Provincial Government has 40 (forty) Regional Apparatus Organizations (OPD). Each Regional Apparatus Organization is led by a Head who is also a Budget User (PA). According to Article 10 of PP No. 12 of 2019, the Budget User (PA) has the following duties: 1. Prepare a Budget Work Plan (RKA-SKPD);2. Prepare Budget Implementation Documents (DPA SKPD); 3. Take actions that result in expenditures on the expense of the budget 4. Carry out the budget of the SKPD they lead.

Budget Users are officials who hold the authority to use the budget of State Ministries/Agencies/Regional Apparatuses. Act as K/L/PD Organizational Leader, have authority over financial management, and become procurement actors In managerial function, can use organizational resources to achieve organizational goals Can perform delegation and mandate functions according to regulations governing For in the regions, have duties and authorities act as PPK.

The implementation of tasks in financial management carried out by the Budget User, and carried out by the Budget User Authority, namely the official who is authorized to carry out part of the authority of the budget user in carrying out some of the tasks and functions of the SKPD. The delegation of part of the authority is determined by the regional head at the suggestion of the head of the SKPD and is based on considerations at the regional level, the size of the SKPD, the amount of money being managed, workload, location, position competence and/or span of control and other objective considerations. The power of the budget user is responsible for the implementation of his duties to the budget user/goods user. The authority of the Budget User is regulated in Presidential Regulation Number 54 of 2010 and its amendments. The delegation of authority between the Budget User and the Budget User Proxy above confirms that the delegation of authority carried out is delegative. Delegative authority is an authority that originates from the delegation of a government organ to another organ on the basis of statutory regulations. In carrying out this authority, the responsibility is borne by the party who is given the authority. If you look at the relationship between the Budget User and the Budget User Proxy, it can be seen that the authority in managing state finances comes from the Budget User and then the implementation is delegated to the Budget User Proxy. Therefore, the responsibility for managing state finances rests with the party delegated the authority, namely the Budget User Authority. In the Organizational Structure of the Regional Apparatus, the Head of the Regional Apparatus Organization is assisted by the Head of Division/Head of Section who also acts as the Budget User Authority (KPA). 
Budget User Proxy (KPA) is an official in the procurement sector determined by the Budget User to use the State Revenue and Expenditure Budget (APBN) or determined by the regional head to use the Regional Revenue and Expenditure Budget (APBD). The power of the budget user, may receive the transfer of authority from the budget user, either in whole or in part. If the power of attorney for the budget user has full authority, then the power of attorney for the budget user can also resolve the dispute between the Working Group of the Procurement Service Unit and the official making the commitment as is done by the user of the budget. The power of the budget user, may receive the transfer of authority from the budget user, either in whole or in part. If the power of attorney for the budget user has full authority, then the power of attorney for the budget user can also resolve the dispute between the Working Group of the Procurement Service Unit and the official making the commitment as is done by the user of the budget .

The power of budget users in the implementation of the APBD is an official who is authorized to carry out some of the authority of budget users in carrying out some of the duties and functions of the regional apparatus. Act as Head of K/L Work Units or Head of SKPD Units, have authority over financial management, and become procurement actors. duties and authorities concurrently as PPK.

\section{LITERATURE REVIEW AND HYPOTHESES Budget Participation}

Brownell (in Mattola, 2011:12) explains that budget participation is a process that involves individuals directly in it and has an influence on the preparation of budget goals whose achievements will be assessed and likely to be rewarded on the basis of achieving their budget goals. Participation involves face-to-face interactions between individual superiors and subordinates to establish a budget that is acceptable to both parties, and employees carry out the necessary activities starting from the beginning of budgeting, negotiating, determining the final budget and revising the required budget.

\section{Job Characteristics}

According to Porter (2015) Job characteristics are defined as the nature of the task which includes the magnitude of the responsibilities and the various tasks carried out by employees. Job characteristics are the nature of employee duties which include the types of tasks, responsibilities, and levels of satisfaction obtained from the characteristics of the work itself (Stoner and Freeman in Sumarsono, 2014). Furthermore, according to Jatmiko (2011), the characteristics of work are showing how much decision making is made by employees on their work, and how many tasks must be completed by employees.

\section{Emotional Intelligence}

According to Daniel Goleman (2016: 43), emotional intelligence is abilities such as the ability to motivate oneself and endure frustration, control impulses and not exaggerate pleasure, regulate moods and keep stress loads from paralyzing the ability to think, empathize and pray. . According to Robbins and Judge (2015: 70) emotional intelligence is a person's ability to detect and manage emotional clues and information.

\section{Work motivation}

According to Hasibuan (2015), motivation comes from the Latin word movere which means encouragement or giving driving force that creates one's work enthusiasm so that someone 
wants to work together, work effectively, and be integrated with all his efforts to achieve satisfaction. Furthermore, Hasibuan (2015) states that work motivation is a condition or energy that moves employees who are directed or aimed at achieving the company's organizational goals. The mental attitude of employees who are pro and positive towards the work situation is what strengthens their work motivation to achieve maximum performance.

\section{Hypothesis}

H1: Budgetary participation determines directly the work motivation of the budget user power of the Riau Islands Provincial Government.

$\mathrm{H} 2$ : Job Characteristics determines directly the work motivation of the budget users of the Riau Islands Provincial Government.

H3: Emotional Intelligence determines directly the work motivation of the budget user power of the Riau Islands Provincial Government.

H4 : Work motivation determines directly the performance of the power of attorney who uses the budget of the Riau Islands Provincial Government.

H5: Budgetary participation determines directly the performance of the budget user power of the Riau Islands Provincial Government.

H6: Job Characteristics determines directly the performance of the budget user power of the employees of the Riau Islands Provincial Government.

H7: Emotional Intelligence determines directly the performance of the budget user power of the employees of the Riau Islands Provincial Government.

\section{RESEARCH METHODS \\ Location and Time}

This research was conducted at the Regional Apparatus Organization (OPD) within the Riau Islands Provincial Government. especially to the Head of Division/Head of Section who in carrying out the activities of the Regional Revenue and Expenditure Budget (APBD) and the State Revenue and Expenditure Budget (APBN) acts as an employee of the Budget User Authority (KPA) in the Riau Islands Province within a period of three months from November 2020 to January 2021. Research begins with literature searches, submission and examination of research proposals, data collection and processing, completing thesis reports to thesis exams.

\section{Research methods}

This research method uses a causal model survey method using path analysis techniques. Based on the reasons, this study aims to confirm the theoretical model with empirical data. This study attempts to test the hypothesis used where this study will take a sample from a population and use a questionnaire as the main data collector.

\section{Population}

The population in this study are employees who work in the power user section of the Riau Islands Provincial Government, totaling 30 people regardless of strata and specific fields of work. Arikunto (in Riduwan, 2012: 210) suggests that if the subject is less than 100, it is better to take all of them, so that the research is a population study. Due to population limitations, all members of the population were used as research samples so that this study used a saturated sample whose collection was carried out through the Census Technique using proportional random sampling. 
Sample

According to Rumengan, et al (2015: 51) what is meant by the sample is part of the population with characteristics that are considered representative of the research population. The sample is part of the population (Umar, 2010; Sekaran, 2011). The sample consists of a number of members selected from the population or subgroups of the population. The sample of this research was taken by descriptive research method with a quantitative approach which aims to show the relationship between variables and the research technique in the form of a survey and the research instrument in the form of a questionnaire. With this method is expected to accurately describe the relationship of independent variables and dependent variables in the study and by using statistics that measure these variables so that it can explain the situation correctly. Descriptive method in the investigation through the activities of telling, describing, analyzing and clarifying the investigation with survey techniques, questionnaires, and observation. Because the sample is used to represent the population being studied, the sample tends to be used for research that seeks to conclude generalizations from the findings.

\section{Data collection technique}

The data collection technique used variable measurement using a questionnaire instrument. Each employee respondent was given five questionnaire instruments to be a source of measurement of the variables studied. Data were collected using the questionnaire method, namely by providing a list of questions or questionnaires to the respondents. The reason for using this method is that the research subjects are the people who know best about themselves, and the statements given by the subjects are true and reliable. Answers to the list of questions that must be filled out by respondents are made using a Likert scale, which ranges from 1 to 5 , where a value of 1 is a statement of strongly disagree and a value of 5 is a statement of strongly agree.

\section{RESULTS AND DISCUSSION Validity and Reliability Test}

Based on the table above, it can be seen that the outer loading values for variables X1, $\mathrm{X} 2, \mathrm{X} 3, \mathrm{X} 4$, Y where values smaller than 0.7 will be dropped out, namely X1.1, , X3.1, X3.7, $\mathrm{X} 4.1, \mathrm{X} 4.8, \mathrm{X} 5.1, \mathrm{X} 5.8$. The rest is greater than 0.7 is declared valid

Based on the table above, the correlation between $\mathrm{X} 1$ and $\mathrm{X} 2$ is 0.821 , the correlation between $\mathrm{X} 1$ and $\mathrm{X} 3$ is 0.704 . The correlation between $\mathrm{X} 1$ and $\mathrm{X} 4$ is 0.680 . The correlation between $\mathrm{X} 1$ and $\mathrm{Y}$ is 0.664 . All variables have a correlation value $<0.900$, thus the correlation value of all variables is declared valid.

Based on the table above, the correlation between $\mathrm{X} 3$ and $\mathrm{X} 2$ is 0.836 . The correlation between $\mathrm{X} 4$ and $\mathrm{X} 2$ is 0.730 . The correlation between $\mathrm{Y}$ and $\mathrm{X} 2$ is 0.767 . All variables have a correlation value $<0.900$, thus the correlation value of all variables is declared valid.

It can also be seen that the table above also shows that the correlation between $\mathrm{X} 4$ and $\mathrm{X} 3$ is 0.754 , the correlation between $\mathrm{Y}$ and $\mathrm{X} 3$ is 0.840 . All variables have a correlation value of $<0.900$, thus the correlation value of all variables is declared valid.

Finally, from the table above, it is also found that the correlation between $\mathrm{Y}$ and $\mathrm{X} 4$ is 0.740 . All variables have a correlation value of $<0.900$, thus the correlation value of all variables is declared valid.

Based on the internal consistency analysis data in the table above, the results show that the $\mathrm{X} 1$ variable has a composite reliability value of $0.925>0.600$ then the $\mathrm{X} 1$ variable is 


\section{Torfai journal \\ Multidiciplinary Output Research For \\ Actual and International Issue}

reliable, then the $\mathrm{X} 2$ variable has a composite reliability value of $0.921>0.600$, the $\mathrm{X} 2$ variable is reliable, the $\mathrm{X} 3$ variable has a reliability value. composite value of $0.923>0.600$ then the $\mathrm{X} 3$ variable is reliable, the $\mathrm{X} 4$ variable has a composite reliability value of $0.895>0.600$ then the $\mathrm{X} 4$ variable is reliable, the $\mathrm{Y}$ variable has a composite reliability value of $0.906>0.600$ then the $\mathrm{Y}$ variable is reliable.

\section{Hypothesis test}

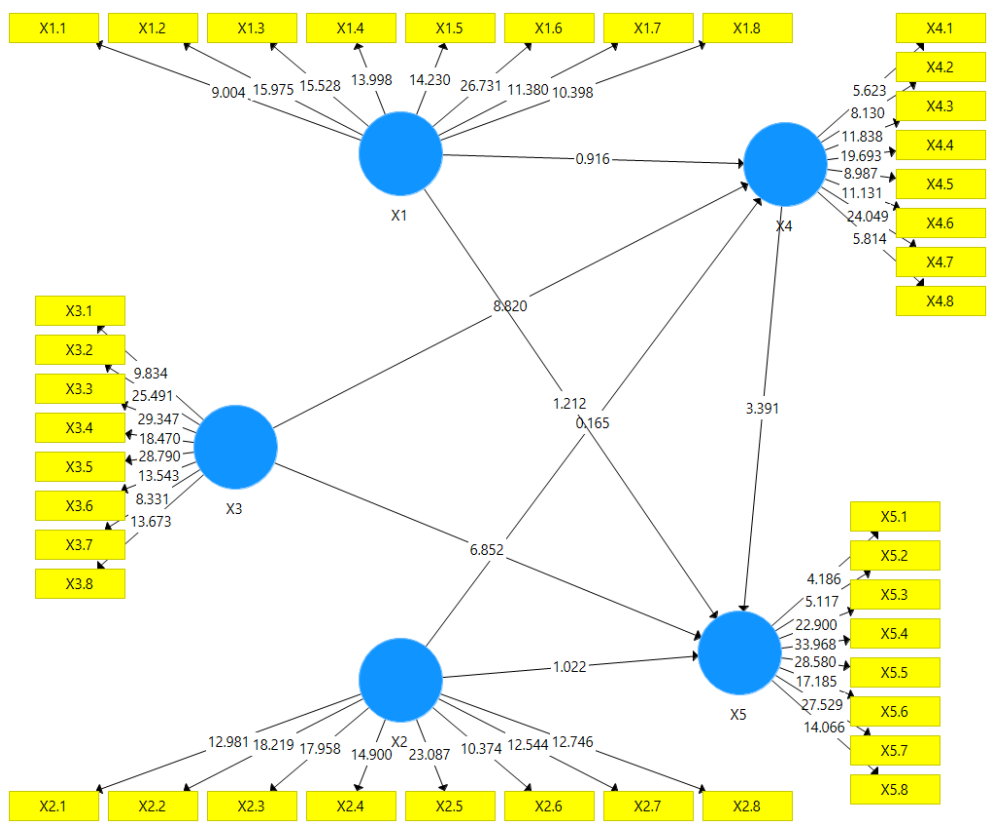

Testing the direct influence hypothesis aims to prove the hypotheses of the influence of one variable on other variables directly (without intermediaries). If the path coefficient value is positive, it indicates that an increase in the value of one variable is followed by an increase in the value of other variables. If the path coefficient value is negative, it indicates that an increase in the value of a variable is followed by a decrease in the value of other variables.

If the probability value (P-Value) < Alpha $(0.05)$ then Ho is rejected (the influence of a variable with other variables is significant). If the probability value (P-Value) $>$ Alpha $(0.05)$ then Ho is rejected (the influence of a variable with other variables is not significant)

\section{Direct Effect Hypothesis}

\begin{tabular}{|c|c|c|c|c|c|}
\hline Variable & $\begin{array}{c}\text { Original } \\
\text { Sample }\end{array}$ & $\begin{array}{c}\text { Sample } \\
\text { Average }\end{array}$ & $\begin{array}{c}\text { Standard } \\
\text { Deviation }\end{array}$ & $\begin{array}{c}\text { T } \\
\text { Statistics }\end{array}$ & $\begin{array}{c}\text { P } \\
\text { Values }\end{array}$ \\
\hline $\mathbf{X 1}$-> X4 & 0.221 & 0.204 & 0.120 & 1,840 & $\mathbf{0 . 0 6 6}$ \\
\hline $\mathbf{X 1}$-> Y & 0.069 & 0.073 & 0.098 & 0.705 & $\mathbf{0 . 4 8 1}$ \\
\hline $\mathbf{X 2}$-> X4 & 0.162 & 0.177 & 0.141 & 1.149 & $\mathbf{0 . 2 5 1}$ \\
\hline $\mathbf{X} 2$-> Y & 0.159 & -0.144 & 0.103 & 1.1541 & $\mathbf{0 . 1 2 4}$ \\
\hline
\end{tabular}




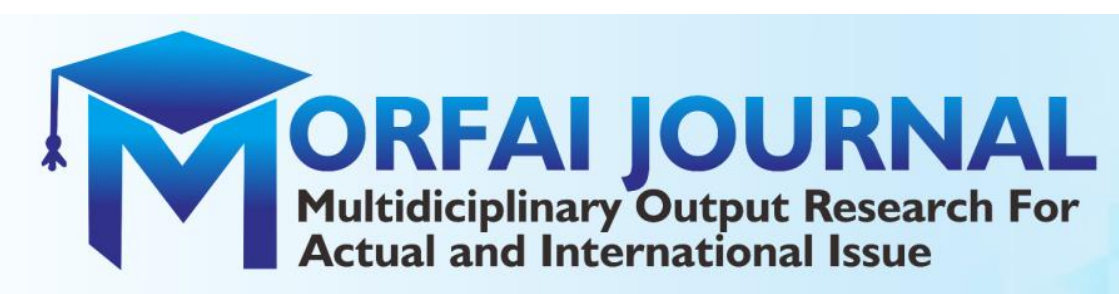

VOLUME I NO.1 (2021)

\begin{tabular}{|c|c|c|c|c|c|}
\hline $\mathbf{X 3} \boldsymbol{~ > ~ X 4 ~}$ & 0.463 & 0.465 & 0.114 & 4045 & $\mathbf{0 . 0 0 0}$ \\
\hline $\mathbf{X 3} \boldsymbol{~ > ~ Y ~}$ & 0.658 & 0.669 & 0.096 & 6.872 & $\mathbf{0 . 0 0 0}$ \\
\hline $\mathbf{X} 4 \boldsymbol{~ - > ~ Y ~}$ & 0.165 & 0.168 & 0.132 & 1,247 & $\mathbf{0 . 2 1 3}$ \\
\hline
\end{tabular}

The direct effect of the X3 variable on the X4 variable has a path coefficient of 4045 (positive), then the increase in the value of the $\mathrm{X} 3$ variable will be followed by an increase in the $\mathrm{X} 4$ variable. The effect of the $\mathrm{X} 3$ variable on $\mathrm{X} 4$ has a $\mathrm{P}$-Values value of $0.000<0.05$, so it can be stated that the effect of $\mathrm{X} 3$ on $\mathrm{X} 4$ is significant.

The direct effect of variable $\mathrm{X} 3$ on variable $\mathrm{Y}$ has a path coefficient of 6.872 (positive), then an increase in the value of variable $\mathrm{X} 3$ will be followed by an increase in variable $\mathrm{Y}$. The effect of variable $\mathrm{X} 3$ on $\mathrm{Y}$ has a $\mathrm{P}$-Values value of $0.000<0.05$, so it can be stated that the effect between $\mathrm{X} 3$ against $\mathrm{Y}$ is significant.

The direct effect of the $\mathrm{X} 4$ variable on the $\mathrm{Y}$ variable has a path coefficient of 1.247 (positive), then the increase in the value of the $\mathrm{X} 4$ variable will be followed by an increase in the $\mathrm{Y}$ variable. The influence of the $\mathrm{X} 4$ variable on $\mathrm{Y}$ has a $\mathrm{P}-\mathrm{V}$ alues value of $0.213>0.05$, so it can be stated that the $\mathrm{X} 4$ against $\mathrm{Y}$ is not significant.

The direct effect of the $\mathrm{X} 1$ variable on the $\mathrm{X} 4$ variable has a path coefficient of 1,840 (positive), then the increase in the value of the $\mathrm{X} 1$ variable will be followed by an increase in the $\mathrm{X} 4$ variable. The effect of the $\mathrm{X} 1$ variable on $\mathrm{X} 4$ has a $\mathrm{P}$-Values value of $0.066>0.05$, so it can be stated that the effect of $\mathrm{X} 1$ on $\mathrm{X} 4$ is not significant.

The direct effect of variable $\mathrm{X} 1$ on variable $\mathrm{Y}$ has a path coefficient of 0.705 (positive), then an increase in the value of variable $\mathrm{X} 1$ will be followed by an increase in variable $\mathrm{Y}$. The effect of variable $\mathrm{X} 1$ on $\mathrm{Y}$ has a $\mathrm{P}$-Values value of $0.481>0.05$, so it can be stated that the effect between $\mathrm{X} 1$ to $\mathrm{Y}$ is not significant.

The direct effect of the $\mathrm{X} 2$ variable on the $\mathrm{X} 4$ variable has a path coefficient of 1.149 (positive), then the increase in the value of the $\mathrm{X} 2$ variable will be followed by an increase in the $\mathrm{X} 4$ variable. The effect of the $\mathrm{X} 2$ variable on $\mathrm{X} 4$ has a $\mathrm{P}$-Values value of $0.251>0.05$, so it can be stated that the effect of $\mathrm{X} 2$ on $\mathrm{X} 4$ is not significant.

The direct effect of the $\mathrm{X} 2$ variable on the $\mathrm{Y}$ variable has a path coefficient of 1.541 (positive), then the increase in the value of the $\mathrm{X} 2$ variable will be followed by an increase in the $\mathrm{X} 4$ variable. The effect of the $\mathrm{X} 2$ variable on $\mathrm{Y}$ has a P-Values value of $0.124>0.05$, so it can be stated that the effect of $\mathrm{X} 2$ on $\mathrm{Y}$ is not significant.

The indirect effect hypothesis testing aims to prove the hypotheses of the influence of one variable on other variables indirectly (through intermediaries). If the coefficient of indirect effect > direct effect coefficient, then the intervening variable is mediating the relationship between one variable and another. On the other hand, if the coefficient of indirect effect is < the coefficient of direct influence, then the intervening variable is not mediating the relationship between one variable and another. 
Indirect Effect Hypothesis Table

\begin{tabular}{|c|c|c|c|c|c|}
\hline Variable & $\begin{array}{c}\text { Original } \\
\text { Sample }\end{array}$ & $\begin{array}{c}\text { Sample } \\
\text { Average }\end{array}$ & $\begin{array}{c}\text { Standard } \\
\text { Deviation }\end{array}$ & $\begin{array}{c}\mathbf{T} \\
\text { Statistics }\end{array}$ & $\begin{array}{c}\mathbf{P} \\
\text { Values }\end{array}$ \\
\hline $\mathbf{X 1 ~}>\mathbf{X} 4$-> Y & 0.036 & 0.035 & 0.038 & 0.957 & $\mathbf{0 . 3 3 9}$ \\
\hline $\mathbf{X 2}$-> X4 -> Y & 0.027 & 0.026 & 0.033 & 0.809 & $\mathbf{0 . 4 1 9}$ \\
\hline $\mathbf{X 3 ~}>\mathbf{X} 4$-> Y & 0.081 & 0.281 & 0.071 & 1.076 & $\mathbf{0 . 2 8 3}$ \\
\hline
\end{tabular}

Based on the table above, the coefficient value of the indirect effect of $\mathrm{X} 1$ on $\mathrm{Y}$ is 0.705 $<0.957$ (direct effect of X1 on Y) thus it can be stated that X4 does not mediate the effect of $\mathrm{X} 1$ on $\mathrm{Y}$.

Furthermore, the coefficient of the indirect effect of X2 on $\mathrm{Y}$ is $1.541>0.809$ (direct effect of $\mathrm{X} 2$ on $\mathrm{Y}$ ) thus it can be stated that X4 mediates the effect of $\mathrm{X} 2$ on $\mathrm{Y}$.

Then, the coefficient of the indirect effect of $\mathrm{X} 3$ on $\mathrm{Y}$ is $6.872>1.076$ (direct effect of $\mathrm{X} 1$ on $\mathrm{Y}$ ) thus it can be stated that $\mathrm{X} 4$ mediates the effect of $\mathrm{X} 1$ on $\mathrm{Y}$.

\section{Coefficient of Determination}

\begin{tabular}{|c|c|c|}
\hline Variable & R Square & Adjusted R Square \\
\hline $\mathbf{X 4}$ & 0.618 & 0.606 \\
\hline Y & 0.732 & 0.721 \\
\hline
\end{tabular}

The table above shows that the effect of X1, X2 and X3 on X4 (e1) is 0.618 , meaning that the magnitude of the effect of $\mathrm{X} 1, \mathrm{X} 2$ and $\mathrm{X} 3$ on $\mathrm{X} 4$ is $61.8 \%$. Then, the effect of $\mathrm{X} 1, \mathrm{X} 3$ and $\mathrm{X} 4$ on $\mathrm{Y}$ is 0.732 , meaning that the magnitude of the effect of $\mathrm{X} 1, \mathrm{X} 3$ and $\mathrm{X} 4$ on $\mathrm{Y}$ is $73.2 \%$.

\section{The Effect of Budget Participation on Work Motivation}

It turns out that budget participation, which is defined as a budgeting approach that allows managers who will be responsible for budget performance, to participate in budget development, budget participation communicates a sense of responsibility to lower level managers and encourages creativity does not significantly affect work motivation as a willingness to spend high effort toward organizational goals, conditioned by the ability of these efforts to meet an individual need

\section{The Effect of Budget Participation on the Performance of Budget Users}

It turns out that budget participation, which is a budgeting approach that allows managers who will be responsible for budget performance, to participate in budget development, budget participation communicates a sense of responsibility to lower-level managers and encourages creativity does not have a significant effect on performance. budget 


\section{ORFAI JOURNAL \\ Multidiciplinary Output Research For \\ Actual and International Issue}

participation has no significant effect on the continuous cycle of improving performance by setting goals, feedback and training, as well as rewards and positive reinforcement.

\section{The Effect of Job Characteristics on Work Motivation}

Job characteristics are defined as the nature of the task which includes the amount of responsibility and the types of tasks carried out by employees. Cannot significantly affect work motivation as a willingness to expend a high level of effort towards organizational goals, which is conditioned by the ability of these efforts to meet an individual need.

\section{The Influence of Job Characteristics on Power Performance}

It turns out that the characteristics of work are defined as the nature of the task which includes the magnitude of the responsibilities and the various tasks carried out by the employee. Not being able to affect performance which in this case is a continuous cycle of performance improvement with goal setting, feedback and training, and significant positive rewards and reinforcement.

\section{The Effect of Emotional Intelligence on Work Motivation}

It turns out that emotional intelligence which is an ability such as the ability to motivate oneself and survive facing frustration, controlling impulses and not exaggerating pleasure, regulating moods and keeping stress loads from paralyzing the ability to think, empathize and pray can significantly affect motivation significantly. encouragement or giving the driving force that creates one's work enthusiasm so that someone wants to work together, work effectively, and be integrated with all his efforts to achieve satisfaction.

\section{The Effect of Emotional Intelligence on Power Performance}

It turns out that emotional intelligence is abilities such as the ability to motivate oneself and endure frustration, control impulses and not exaggerate pleasure, regulate moods and keep stress loads from crippling the ability to think, empathize and pray. Able to significantly influence performance which is a continuous cycle of improving performance with goal setting, feedback and training, as well as positive rewards and reinforcement.

\section{The Effect of Work Motivation on Power Performance}

The direct effect of the $\mathrm{X} 2$ variable on the $\mathrm{Y}$ variable has a path coefficient of 1.541 (positive), then the increase in the value of the $\mathrm{X} 2$ variable will be followed by an increase in the X4 variable. The effect of the X2 variable on Y has a P-Values value of $0.124>0.05$, so it can be stated that the effect of $\mathrm{X} 2$ on $\mathrm{Y}$ is not significant.

It turns out that motivation comes from the Latin word movere which means encouragement or the provision of a driving force that creates one's work enthusiasm so that someone wants to work together, work effectively, and be integrated with all his efforts to achieve satisfaction. goals, feedback and training, and positive rewards and reinforcement.

\section{CONCLUSION, LIMITATIONS AND SUGGESTIONS}

\section{Research Limitations}

This study has several limitations that may interfere with the results of the study. These limitations include: The data of this study were generated from instruments that were built from theory and then developed into questions based on respondents' answers in the form of a Likert scale. This raises many problems including the psychological factor of the respondent in 
answering the questionnaire so that it contains a very high subjective element. In addition, this research is based on a survey method through questionnaires, the researchers did not conduct interviews, so the conclusions raised are only based on the data collected through tabulations which are managed using path analysis data analysis tools so that between researchers and respondents do not interact directly or do not create a relationship. as well as in-depth interactions in interpreting research for future theory development.

\section{Conclusion}

The findings of data analysis in the discussion and hypothesis testing, it can be concluded as follows:

The direct influence of the Emotional Intelligence variable on the Work Motivation variable has a path coefficient of 4045 (positive), then the increase in the value of the Emotional Intelligence variable will be followed by an increase in the Work Motivation variable. The influence of the Emotional Intelligence variable on Work Motivation has a P-Values value of $0.000<0.05$ so it can be stated that the influence of Emotional Intelligence on Work Motivation has a significant effect.

The direct effect of the Emotional Intelligence variable on the Performance variable has a path coefficient of 6.872 (positive), then an increase in the value of the Emotional Intelligence variable will be followed by an increase in the Performance variable. The influence of the Emotional Intelligence variable on Performance has a P-Values value of $0.000<0.05$ so it can be stated that the influence of Emotional Intelligence on Performance is a significant effect. The direct effect of the work motivation variable on the performance variable has a path coefficient of 1.247 (positive), then the increase in the value of the work motivation variable will be followed by an increase in the performance variable. The influence of work motivation on performance has a P-value of $0.213<0.05$ so it can be stated that the effect of work motivation on performance has a significant effect.

The direct influence of the Budget Participation variable on the Performance variable has a positive path coefficient, the direct effect of the $\mathrm{X} 1$ variable on the $\mathrm{Y}$ variable has a path coefficient of 1,840 (positive), then the increase in the value of the $\mathrm{X} 1$ variable will be followed by an increase in the $\mathrm{Y}$ variable. The influence of the $\mathrm{X} 1$ variable on $\mathrm{Y}$ has a $\mathrm{P}-$ Values value of $0.066>0.05$, so it can be stated that the effect of $\mathrm{X} 1$ on $\mathrm{Y}$ is not significant.

The direct effect of the Job Characteristics variable on the Work Motivation variable has a positive path coefficient, the direct effect of the $\mathrm{X} 2$ variable on the $\mathrm{X} 4$ variable has a path coefficient of 0.705 (positive), then the increase in the value of the $\mathrm{X} 2$ variable will be followed by an increase in the $\mathrm{X} 4$ variable. The effect of the $\mathrm{X} 2$ variable on $\mathrm{X} 4$ has a $\mathrm{P}$-Values value of $0.481>0.05$, so it can be stated that the effect of X2 on X4 is not significant.

The direct effect of the Job Characteristics variable on the Performance variable has a positive path coefficient, the direct effect of the $\mathrm{X} 2$ variable on the $\mathrm{Y}$ variable has a path coefficient of 1.149 (positive), then the increase in the value of the $\mathrm{X} 2$ variable will be followed by an increase in the $\mathrm{X} 4$ variable. The effect of the $\mathrm{X} 2$ variable on $\mathrm{Y}$ has a P-Values value of 0.251 $>0.05$, so it can be stated that the effect of $\mathrm{X} 2$ on $\mathrm{Y}$ is not significant.

The direct influence of the Budget Participation variable on the Work Motivation variable has a positive path coefficient, the direct effect of the X1 variable on the X4 variable has a path coefficient of 1,541 (positive), then an increase in the value of the $\mathrm{X} 1$ variable will be followed by an increase in the X4 variable. The effect of the X1 variable on X4 has a P-Values value of $0.124>0.05$, so it can be stated that the effect of $\mathrm{X} 1$ on $\mathrm{X} 4$ is not significant. 


\section{Suggestion}

1. The participation of government officials is very much needed in improving performance. Due to the lack of participation in the opinion of the planning of budget preparation, policy makers should pay more attention to the opinions of local government officials and the priority needs of the community.

2. The researcher suggests the need to consider job characteristics and describe the real characteristics that now exist in each job and know the standards and abilities in each job so that employee performance can be better and goals can be achieved.

3. Researchers suggest the need to manage conflicts between co-workers with their emotional intelligence so that conflicts can be resolved, so as not to hinder work that can reduce performance in the organization.

4. Researchers suggest the need to pay close attention to the needs of employees, not only incentives, but also other basic needs such as completeness of work facilities, working room conditions, and auxiliary tools at work, besides that supervision and control of employees also needs to be improved so that employees can work according to expectations and more efficient use of their working time.

5. The researcher suggests the need to carry out internal control over the process of effectively absorbing budget funds received from the government, in order to find out how the employee's performance is in accordance with the regulations and targets expected for this activity process and also there is no misappropriation of budget use funds and can show evidence- evidence that the activity has been carried out, besides that it can also see what activities need to be carried out first, what activities do not require too much budget funds, and what activities have not been carried out in that year, so that the budget absorption process can be optimal.

\section{REFERENCES}

Abdul, Masaong K. and A. Tilomi. 2011. Multiple Intelligence Based Leadership. Bandung : Alphabet.

Analysis, Lucky Wulan. 2011. Analysis of the Influence of Work Motivation and Work Environment on the Performance of DISPERINDAG employees in Semarang City. Essay. Faculty of Economics: Diponegoro University Semarang

Andrie Jatmiko. 2011. The Effect of Job Characteristics and Work Culture on Employee Job Satisfaction at the Nusantara Cooperative, Soreang Unit Office. Thesis Management Study Program Faculty of Economics, University of Pasundan Bandung.

AA Anwar Prabu Mangkunegara (2012). Human Resource Management. Bandung: PT. Rosdakarya Youth.

Great Panudju. 2014. The Effect of Compensation and Job Characteristics on Job Satisfaction of Employees of Unit PT. X Palembang. Sriwijaya Journal of Management and Business. Retrieved April 10, 2019.

Anoraga, Panji. 2014. Occupational Psychology. Jakarta : Rineka Cipta

AA Anwar Prabu Mangkunegara 2015, Human Resource Management Company, Bandung Publisher: Youth Rosdakarya

Wake up, Wilson. 2012. “Human Resource Management”. Jakarta: Erlangga. 
Dessler, Gary. 2010. HRM. 10. Translated by Paramitha Rahayu.: Permata Puri., Jakarta

Dharmanegara, Ida Bagus Agung. (2010). Corporate Budgeting: Theory and Application. Yogyakarta: Graha Ilmu.

Dharmanegara, Ida Bagus Agung., (2010), Corporate Budgeting. First Edition, Graha Ilmu Publisher, Yogyakarta.

Garrison, et al. (2013), Managerial Accounting, Jakarta: Salemba Empat.

Garrison, Ray H, Norren, Brewer. (2013). Managerial Accounting. Jakarta: Four Salemba.

Goleman, Daniel (2015). Emotional Intelligence : Emotional intelligence why EI is more important than IQ, Jakarta: PT. Main Library Gramedia

Goleman, Daniel (2015). Emotional Intelligence: Why EI is more important than IQ, trans. T. Hermaya, Jakarta: Gramedia Pustaka Utama.

Hansen, D. R, and Mowen, M 2013, Managerial Accounting, Book 1, Edition 8, Salemba Empat, Jakarta.

Hasibuan, PS Malay. 2015. Human Resource Management, Publisher : PT. Earth Literacy, Jakarta

Hasibuan, Malay SP. 2017. Human Resource Management. Revised Edition. Jakarta: Earth Literacy.

Ilham, Rico Nur et all. (2019). Investigation of the Bitcoin Effects on the Country Revenues via Virtual Tax Transactions for Purchasing Management. International Journal of Suplly Management.Volume 8 No.6 December 2019.

Ilham, Rico Nur et all. (2019). Comparative of the Supply Chain and Block Chains to Increase the Country Revenues via Virtual Tax Transactions and Replacing Future of Money. International Journal of Suplly Management.Volume 8 No.5 August 2019.

Khaddafi, M. ., Aryani, R. A., \& Heikal, M. . (2021). The Effect Of Financial Knowledge And Personal Net Income On The Financial Behavior Of Malikussaleh University Employees With Locus Of Control As Moderating Variables. International Journal of Economic, Business, Accounting, Agriculture Management and Sharia Administration (IJEBAS), 1(1), 1-13. https://doi.org/10.54443/ijebas.v1i1.1

Kreitner, Robert and Angelo Kinicki. 2014. Organizational Behavior. Edition 9. Book 1. Jakarta: Salemba Empat.

Lavarda, Carlos and Almeida, D., 2013. Budget Participation and Informational Asymmetry: a study in a multinational company. Brazilian Business Review. Vol. 10, No. 2. PP. 72-94.

Mowen / Hansen. 2013. Managerial Accounting. Salemba Four. Jakarta

Nurcahyani, 2010. The Effect of Budget Participation on Managerial Performance Through Organizational Commitment and Perception of Innovation as an Intervening Variable. Faculty of Economics, Diponegoro University

Primary, Reno. 2013. "The Influence of Budget Participation on Budgetary Slack with Organizational Commitment and Motivation as Moderators (Empirical Study on SKPD in Padang City)". Thesis, Faculty of Economics, Padang State University.

R. Nur Ilham, M. . Sumatrani Saragih, and A. . Saifannur, "Effect Of Working Capital Management And Leverage On Company Value With Profitability As Moderating Variables: Empirical Study On Manufacturing Companies Listed On The Indonesia Stock Exchange", IJEBAS, vol. 1, no. 1, pp. 41-53, Oct. 2021. 


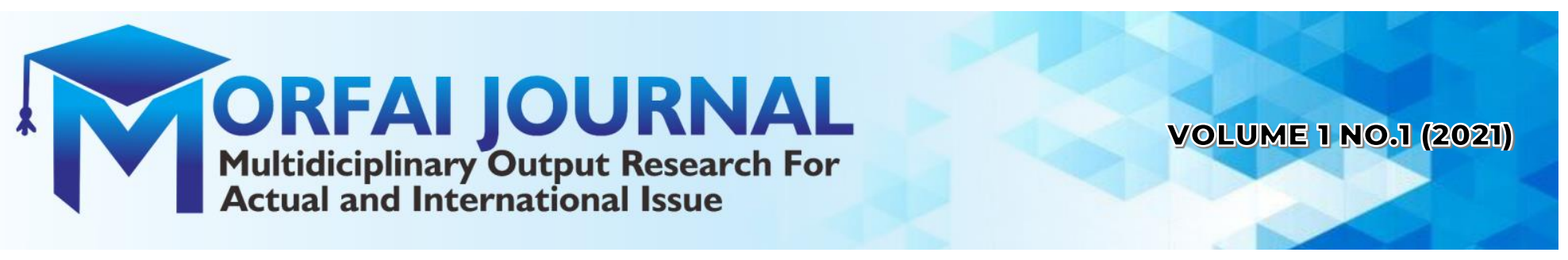

Robbins, P. Stephen and Mary Coulter. 2010. Management, translated by Bob Sabran, Wibi Hardani. Erlangga: Jakarta.

Ridwan Mattola. 2011. The Effect of Budget Participation on Performance With Locus Of Control As Moderating Variable. Thesis of the Faculty of Economics, Hasanuddin University, Makassar.

Rivai, Veithzal. 2011, Human Resource Management for Companies: from Theory to Practice, Jakarta : RajaGrafindo Persada

Risma, Devi. 2012. "The Effect of Emotional Intelligence on Employee Performance: Experimental Research". Educhild. Vol.1 No.1. Riau: FKIP UNRI.

Robbins, Stephen P \& Judge, Timothy A. 2013. Organizational Behavior Edition 15. New Jersey: Pearson Education

Robbins \& Judges. 2015. Organizational Behavior Edition 16. Jakarta. Salemba Four.

Rumengan Jemmy/Satriawan Bambang/Juliandi, Azuar/Irfan, (2011), Path Analysis with SPSS, Diktat lectures and training. BATAM: UNIBA

Rumengan Jemmy, Juliandi Azuar, Gaddafi Muammar, Rumengan Eleonora Angelina 2019. Research Methods. Sefa Bumi Persada ISBN-978-602-0768-85-4.

Rumengan Jemmy, Gaddafi Muammar, Syarif Arman, Yanti Sri 2020. Research Methodology. Sefa Bumi Persada. ISBN-978-623-7648-57-4.

Rumengan Jemmy, Suhardis Adnan, Rumengan Tommy 2020. Health Research Methodology. Sefa Bumi Persada ISBN-978-623-7648-49-9.

Sedarmayanti. 2011. Human Resource Management, Bureaucratic Reform and Civil Service Management (fifth edition). PT Refika Aditama. Bandung

Sumarsono. 2014. Sociolinguistics. Yogyakarta: Student Library.

Sunyoto, Danang. (2015). Human Resources Research. Jakarta: Fun Books.

Winardi. 2011.Leadership in Management, PT. Rineka Cipta. Jakarta.

Wibowo. 2013. Behavior in Organizations.. Jakarta: PT. King Grafindo Persada 